\title{
Methodological Analysis of Financial Corruption Typology Schemes in Public Procurement Area
}

\author{
Aiganysh Israilova*, Karel Tomšík \\ Department of International Relations, Czech University of Life Sciences Prague, Praha, Czech Republic \\ Email: *israilova@pef.czu.cz
}

How to cite this paper: Israilova, A., \& Tomšík, K. (2021). Methodological Analysis of Financial Corruption Typology Schemes in Public Procurement Area. Open Journal of Social Sciences, 9, 306-316.

https://doi.org/10.4236/jss.2021.912021

Received: November 11, 2021

Accepted: December 18, 2021

Published: December 21, 2021

Copyright ( 2021 by author(s) and Scientific Research Publishing Inc. This work is licensed under the Creative Commons Attribution International License (CC BY 4.0).

http://creativecommons.org/licenses/by/4.0/

\begin{abstract}
This article is devoted to the analysis of corruption schemes taking place in the field of public procurement. An attempt has been made to analyze the identification of an affiliated relationship between all participants in a corruption crime and also proposed necessary conditions for assessing corruption risks, to which should be paid primary attention in procurement and tenders. In this article, historical comparative analysis was made including possible theories focused on object, as well as working with data and their empirical interpretation.
\end{abstract}

\section{Keywords}

Corruption, Public Procurement, Financial Schemes, Typology, Convention, Affiliation, Contractor, Consumer

\section{Introduction}

Anti-corruption and money laundering issues have become a priority and have become global in nature. The most ambitious international document calling for the integration of countries against corruption was the UN Convention against Corruption, adopted by General Assembly resolution 58/4 of October 31, 2003 (United Nations Convention against Corruption, 2004).

To ensure the economic security of the countries of the world fighting corruption and transnational crime in the field of money laundering, the following international normative legal acts were adopted:

- Council of Europe Criminal Law Convention on Corruption, Strasbourg on 27.01.1999 (Council of Europe Criminal Law Convention on Corruption, 1999); 
- Convention on Combating Bribery of Foreign Public Officials in International Business Transactions, Paris on 17.12.1997 (OECD, 1997);

- Council of Europe Civil Law Convention on Corruption, Strasbourg on 4.11.1999 (Council of Europe Civil Law Convention on Corruption, 1999).

All these regulations have a wide scope and are aimed primarily at active and passive bribery of national and foreign government officials, bribery in the judicial system, personal enrichment through the legalization of illegally obtained income through crimes in the field of banking, tax, currency legislation.

The Pittsburgh G20 Summit Pennsylvania, USA, took place on September 24-25, 2009, which was the third meeting of state and government heads from G20 countries dedicated to global financial crisis corruption according to the FATF recommendations (G-20 Summit, 2009).

Progressive governments aimed at having efficient Public Finance Management for resources efficient management and to maximize opportunity costs associated with Public Procurement (Muwema \& Phiri, 2020). Today corruption has become one of the main topics of discussion between politicians at all levels of government. Moreover, the anti-corruption team is always discussed at meetings of the government and parliament, in the media and, of course, at international scientific conferences and round tables. In many respects, the adopted resolutions and agreements are not implemented with the greatest efficiency, so one can argue about the increasing role of corruption.

Despite the anti-corruption measures taken by the state and the gradual improvement of mechanisms for unifying common approaches to the regulation of anti-corruption measures, the problem of corruption remains a serious problem for the modern European and Asian economies. A study of corruption forms including their types contained in a scientific publications by a group of Norwegian scientists (Gendler \& Paksyutkin, 2006). Corruption essence is a socio-economic phenomenon characterized as illegal monetary relations, a set of certain illegal attitudes and principles in subjects of social activity (Khabibulina, 2011). According to estimates by international anti-corruption movement Transparency International in 2016, corruption and bribery in Kyrgyzstan are among the three most difficult problems requiring solution (Ivanov, 2018). Corruption differs only in scale prevalence and level of penetration into society and the government system (Baigubatova \& Sarmanova, 2018).

\section{Research Methods and Materials}

In this article, historical comparative method including analysis of possible theories focused on object, as well as working with data and their empirical interpretation (Rezaev \& Tregubova, 2012), philosophical (Edronova \& Ovcharov, 2013) and formal analysis (Bystryantsev, 2009) methods were used.

\section{Results and Discussions}

Considering the corruption essence (Mangafić \& Veselinović, 2020), it is impor- 
tant to answer the questions: what is the corruption nature, its causes and impact on the government, society (Abu \& Staniewski, 2019) and the economy as represented in Figure 1 (Bahoo et al., 2021), and most importantly, is it possible to successfully fight in modern conditions.

As we noted above, one of the main international acts against corruption is the 2003 UN Convention, which is aimed at four main vectors:

1) Law enforcement activities in governments (including effective anti-corruption government policy, as well as independence in the activities of all jurisdictional bodies in solving corruption crimes);

2) Preventive measures to combat corruption at the government organs level (openness, transparency and accessibility of obtaining information on government bodies financial condition and financial transactions on public procurement and tenders, automation of work and transparency in the reports of civil servants);

3) Preventive measures in the economy private sector (prevention of corporate fraud and misleading consumers, fictitious bankruptcy, etc.);

4) Effective risk assessment and financial monitoring, as well as an active position of government in international cooperation on exchange of fugitive criminals, return of stolen assets, confiscation as a measure to ensure the execution of punishment (United Nations Convention against Corruption, 2004).

\section{Problem Study Objectives}

Corrupting individuals implicated by phenomenon while engaging in social relations and situated in different contexts (Pertiwi, 2018), and negatively affects relationship between the government and civil society. The scale of economy

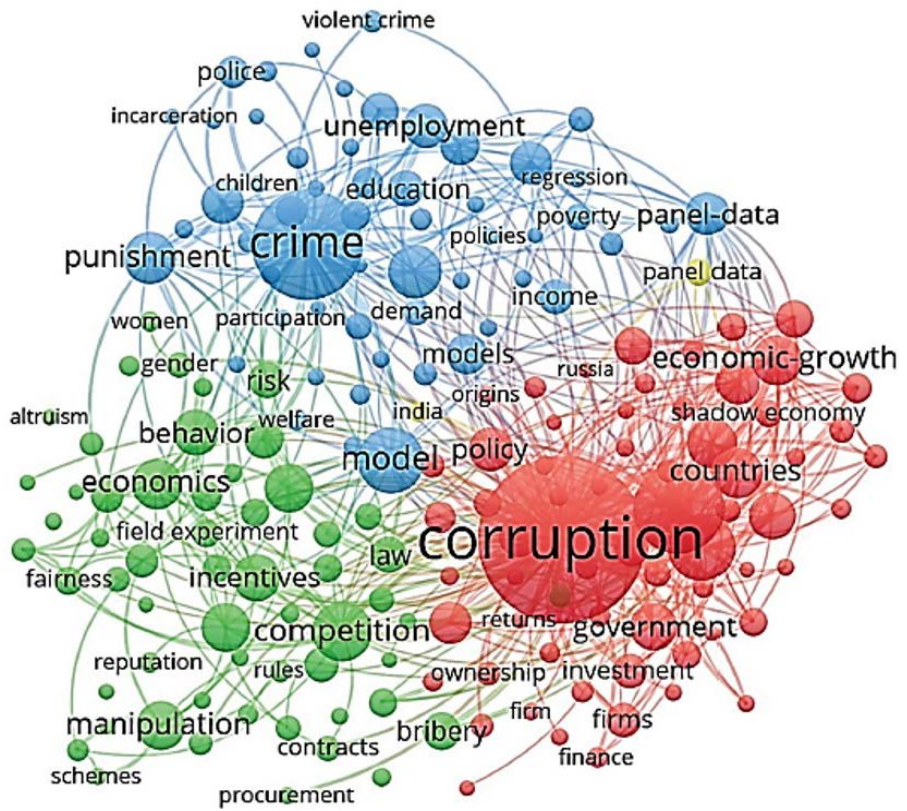

Figure 1. Keyword analysis to identify research areas in the literature through cartography analysis (represented from Bahoo et al., 2021). 
shadow under the influence of corruption in Kyrgyzstan remains at a high level only in the field of entrepreneurship, its level reach 37\% of GDP in 2019 (Asian Development Bank, 2020).

According to a statistical study conducted in 2019, respondents consider the following government structures as corrupting bodies: Internal Affairs Ministry, Health Ministry, Economy Ministry, Customs Service, Government Penitentiary Service and the Government Fund for Government Property Management.

In this regard, we propose schematically consider known components in corruption typologies, depending on source of illegal income and the subjects participating in corruption schemes. Typology analysis of financial schemes for money laundering through corruption shows their quality and quantity in almost all world countries. The most general schematic proposals for such types of corruption activity include the following components as shown in Figure 2.

Acceptance of cash remains as the most popular and simplest source of illegal profit. Moreover, its scale allows one to conclude the true scale of corruption and, accordingly, the alleged and desired excess profits of bribe-giver. Resonant cases of taking bribes in different countries, for example, in Russia, during a search of the former governor of the Sakhalin Region, cash found for almost 1 billion rubles, received as a kickback when concluding a contract for construction of fourth power unit in Yuzhno-Sakhalinsk heat power station and transferred through an intermediary (Forbes, 2021).

The largest bribe of 500 thousand dollars in the Kyrgyz Republic, accepted in cash, was 200 thousand US dollars, which received by head of department for maintaining the government prosecution and representation in the courts of General Prosecutor's Office U. Chalbaev for mitigating the sentence of ex-parliamentarian K. Samakov (KG24, 2021).

However, the corrupt officials realized that accepting bribes directly in cash is becoming very dangerous, and therefore, since the beginning of 2000, new schemes, more sophisticated, requiring certain knowledge and experience of such investigations, have spread. Given the intricate chain of transit payments between final transactions (cashing out or withdrawing money abroad) and the real beneficiaries of financial transactions, it has become more difficult to determine and identify shares of participants in corruption schemes, since, ultimately, they run into tax havens or offshore zones. Financial monitoring carried out in various countries following the FATF recommendations also made it possible to determine the essence of dubious transactions through banking operations and identify criteria for assessing banking risks.

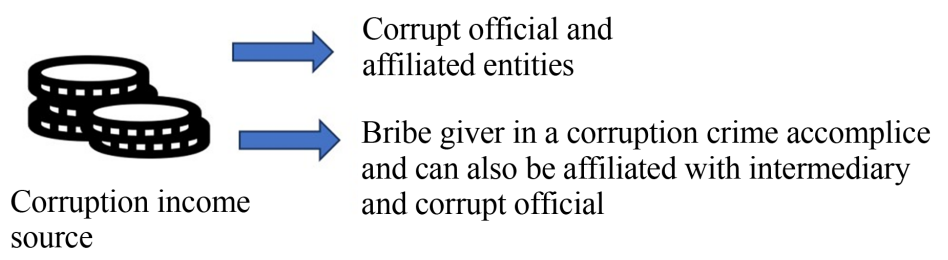

Figure 2. Corruption activity scheme. 
Risk assessment applies to all economic sectors; however, the practice has proven the most popular economy sector among corrupt officials. Among them, the leading position in the construction industry and the movement of goods without declaring through customs borders, then in goods trade, provision of services and logistics in amount of $\$ 386$ million allocated by China as a loan showed weakness of government control and accounting of budgetary funds.

\section{Corruption Schemes Analysis}

An analysis of corruption schemes is impossible without a study of its subject composition, the main figures in which are directly the corrupt official and the bribe-giver. This list can be expanded by an intermediary, bank employees, family ties, which is a generalized form we can call persons affiliated with criminals.

How is the affiliation of such ties manifested? Before identifying the links between these entities, we note that the term "affiliated persons" is used in the laws of many countries. This is due to the desire to ensure that the interests of honest taxpayers, entrepreneurs, foreign investors and shareholders are protected from possible abuse of the position of individuals. According to the Kyrgyz Republic Law “On Conflict of Interests" from December 12, 2017 No. 206 (11), an affiliate is a person who meets one or more criteria determined by the legislation on public procurement (Kyrgyz Republic Ministry of Justice, 2017).

Effective from January 1, 2018, amendment to the Czech Republic Act No. 304/2013 Coll. "On Czech Public Registers of Legal Entities and Natural Persons and the Register of Trusts ('Public Registers Act')" came to force, in which the obligation of legal entities to a public register, and trusts for mandatory registration (recording) of their beneficial owners in a private register section "register of beneficial owners". The beneficial owner definition based on Law No. 253/2008 Coll., "On Certain Measures for Money Laundering and Terrorist Financing" (ZAKONY, 2013).

According to Chapter 2 of Part 10 of the UK Companies Act 2006, the Director is obliged to act independently within powers in the company interests and to show reasonable care, skill and discretion in management, is obliged to avoid conflicts of interest, refrain from gifts and other benefits provided by third parties is obliged to declare its interest in the company's transactions for violation of these obligations, administrative, disciplinary, civil and criminal liabilities (Legislation. gov.uk, 2006).

Thus, affiliated entities identifying process is of great practical importance and can actually manifest itself in only two cases: 1) when a corrupt official extort bribes on his own, all the simple elements of a crime are present here; 2) when two or more persons are involved in corruption: a corrupt intermediary-bribe-giver. We think that it is not difficult to identify the affiliation between subjects and we propose to consider their relationship and sources in Figure 3.

In any scheme of tracing the affiliated connection between the subjects, the corrupt official acts as a crime organizer. Methods of carrying out financial frauds 
prove connection between their control and execution. For example, a corrupt organizer can act as a public official or an official of a legal entity as a direct manager, or as a person indirectly managing a corruption scheme. Financial corruption schemes analysis and practice of government fight against corruption allows us to testify multiplicity of such schemes, among which we will single out the most common items.

In particular, in recent years, bank financing of speculative foreign trade operations and illegal transactions within the country has become widespread. This action acquires a particular social danger resulting in government bodies' participation in material purchases in this scheme at expense of budgetary funds. Vital goods (for example, expensive equipment for the treatment of oncological diseases) are imported into the country under government order at prices same to their cost, which minimizes or completely avoid payment of customs duties. However, when settling with the government, an amount indicated as significantly higher than the purchased one, the price difference appropriately used to cover corruption incomes. Such a scheme is quite common among corruption schemes committed by officials in Kyrgyzstan.

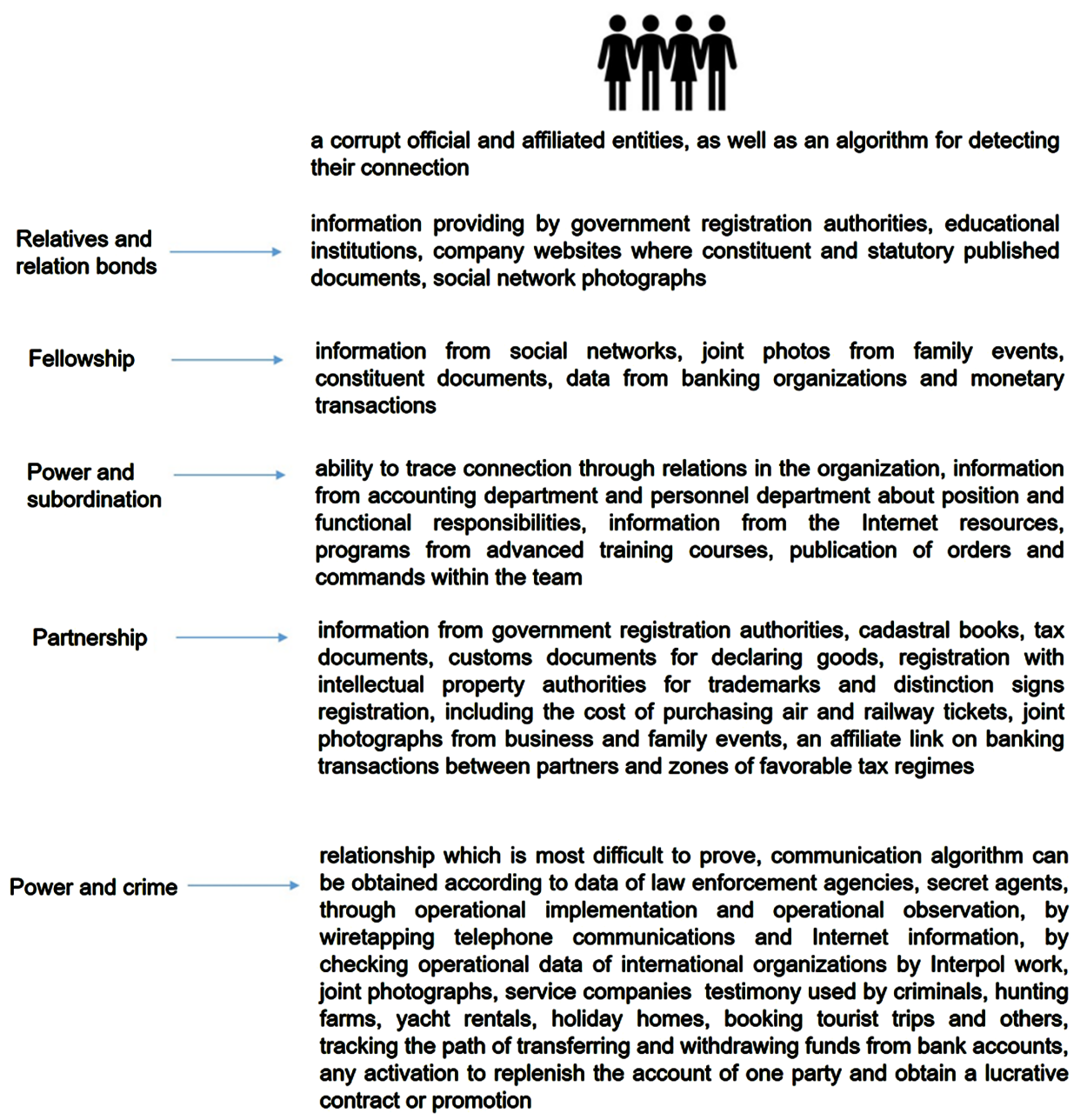

Figure 3. Examples of affiliation between subjects. 


\section{Corruption Scheme Examples}

Thus, in case of former mayor and Kyrgyz Parliament deputy N. Tyuleev, the court issued a sentence of imprisonment for 11 years with complete confiscation of property and compensation for material damage over 1 million US dollars. The plot of case is as follows: Tyuleev, as mayor accused of corruption in public procurement when he bought buses in China at an overpriced price in 2008 and then entered into an unjustified contract for their delivery to the republic. As a result, the state suffered damage for $\$ 1.5$ million, and the funds for buses to China transferred through Dos-Kredobank OJSC, where Tyuleev had 19\% - 20\% of capital.

Analyzing corrupting actions algorithm in a public procurement, at the forefront investigation it is necessary to highlight degree of subjects' affiliation. If we analyze the above example of convicted mayor of Bishkek N. Tyuleev, then the level of subordination is manifested here.

Thus, Tyuleev and his 9 colleagues, employees of the mayor's office and other state bodies participating in the tender, were charged under articles 30, part 4 ("complicity in a crime"), 303 part 1 ("Corruption"). As part of the investigation of this criminal case, it was revealed that ineffective spending of state budget funds caused major damage to the state, and these corrupt actions were committed with the aim of embezzling budget funds and at the same time aimed at extracting personal benefits from the relevant officials. Such persons are designated according to Article 26 of the Kyrgyz Republic Criminal Code as a "special entity" and a civil servant endowed with broad official powers. This corruption crime was carried out in several stages: the announcement of a tender, consideration of proposals and payment of the contract. The controlling government role in assessing corruption risks in management of budget finances is of great importance here. Such work was not carried out efficiently and corruption risks arose already at stage of announcing a government tender since initially, it was possible to recognize such a transaction as suspicious for at least one fact that amount of damage caused went directly to foreign campaign "Sin-Hai-Teng", head of which is Wang Hai Bin, and in which Tyuleev and his accomplices were interested. It was established that there was a long-standing before the announcement of public procurement tender, affiliate relationship between all participants in this case. Well, and accordingly, all other stages of this scheme were criminal.

An equally sophisticated method of corruption schemes that is gaining moment is so-called "corruption Latin" scheme. Scientific analysis of the experience of fighting corruption in foreign countries did not provide enough information; we think that such a criminal practice took place only in Russia, Kazakhstan and Kyrgyzstan (Newsru.com, 2013).

The meaning of such scheme is simple enough to implement laborious to detect, and it is required to involve specialists in the IT technologies the field of to disclose such schemes. That is, when placing a state order on the official web- 
sites of ministries, letters with similar spelling from the Cyrillic and Latin alphabet are used. However, even replacing only one letter entails the impossibility of determining and identifying the necessary keyword for the search in the registry. This scheme allowed for some time to completely exclude competition in participation in state competitions and tenders, since the "corrupt Latin alphabet" was used by officials so that the state order could only find and "fulfill" their contractor. As a rule, in order not to attract undue attention and not give reason to consider such a transaction suspicious, several contractors were allowed to participate, but they were clearly all affiliated with the main customer. An official places an application on the public procurement website, replacing similar Cyrillic letters in words with Latin letters, such as: a, e, o, y, c, K, T, B, M, H.

Thus, on official website of public procurement in Kyrgyzstan, less than in 2016, at least 72 tenders with use of "corrupt Latin alphabet" were hidden. The total amount of discovered hidden tenders was more than the US \$9 million. The largest tender of the Department of Internal Affairs of Osh city in amount of more than 6 million US dollars after a scandal raised by independent media in the Department of Public Procurement under Ministry of Finance was canceled

This practice despite the government reaction remains valid and does not entail severe punishment concerning the tender organizers. In this regard, we propose the simplest option for combating corruption in the Latin alphabet as automating determination of all conditions and methods for holding tenders and making changes in software of government official website on procurement. Such a modern and inexpensive method is able to automatically monitor offered prices, know information about the contractors' business reputation, but most importantly, regardless of writing letters in Cyrillic or Latin.

\section{Conclusion}

In summary, along with a clear definition of corruption risks, we highlight corruption signs in the public procurement field: application of Latin or Russian alphabet when announcing a tender; registration of only one participant in auction; announcement of conditions that put some participants in tender in advance unfavorable conditions (for example, company sells medical equipment, however, according to tender terms, procurement list includes not only equipment but also medicines, uniforms and medical furniture, which naturally creates difficulties for a narrow-profile company meet all conditions); suspiciously high contractor price that goes beyond the terms of other contractors; complete lack or contractor's commercial activities insufficient information on the website; suspicious banking transactions, cash withdrawals, tax payment claims and bank transfers outside the contractor scope; suspicious banking transactions of nature transit, or placement of accounts in offshore zones. The contractor has been in the service market for a very short time, however, with the help of a massive and aggressive advertising campaign, he himself is a serious businessman; if corrupt affiliation of customer and contractor, as well as their family members, friends, 
fellow countrymen, colleagues and other connections should arouse great suspicion in all banking operations, replenishment of bank accounts for a large amount of the customer and his family members for period of tender announcement. In addition to replenishing a bank account, it is necessary to check customer and his family large purchases, expensive trips and travels; great suspicion appears by activation in social networks of young members of customer's family, where photographs of purchased expensive cars, real estate, jewelry, branded clothing and travel to expensive resorts and so on are posted. This list is not exhaustive, however, practice shows that when assessing risks and conducting financial monitoring, the regulatory authorities should pay maximum attention to all little things that will suspect a corrupt official, a civil servant and a bribe-giver-a contractor in a conspiracy to commit a corruption offense.

There are several specific corruption typologies in public procurement:

1) Participation in government tenders and proxies with two main objectives: a) to reduce the declared project price; b) according to a previously agreed-upon scheme for eliminating competitors by introducing inaccuracies in project name, in the terms of offers. Here, it is of great importance to check the affiliate relationship between the customer and the contractor.

2) Participation in tender of specially created for these purposes fly-by-night firms, created by persons affiliated to the customer, basically the affiliated relationship power - subordination and colleagues falls under this category when the tender wins his own front participant who does not have an obvious goal of high-quality work performance, that is, a complete lack of control on the part of the customer.

3) Involvement of foreign investor companies in bribing officials to increase sales. This scheme recognized as one of largest sales in terms and virtually all signs of corruption risks. First, this is a clearly inflated price, payment for the performance of work and the provision of services strictly through transit accounts located in tax-favored zones and connection discovery between bidders. Corruption scandals related to highest authorities and the world's largest companies such as Samsung, Hewlett-Packard, Siemens and Deutsche Bank similarly took place.

Deploring corruption problem in public procurement system is remaining as acute and unresolved at present in almost all countries. It was recognized, that most corrupting spheres in public procurement today are the following: construction, including housing, road construction and repair, education and healthcare.

The downward trend in public procurement corruption has not begun to decline, despite the tightening of responsibility, the increase in prison terms and the number of fines, the government is hardly capable of fighting a corrupt official.

This social pandemic has hit the public procurement industry. Corruption damages public finances by negatively influencing public services in building 
schools and providing quality health care.

\section{Conflicts of Interest}

The authors declare no conflicts of interest regarding the publication of this paper.

\section{References}

Abu, N., \& Staniewski, M. W. (2019). Determinants of Corruption in Nigeria: Evidence from Various Estimation Techniques. Economic Research-Ekonomska Istraživanja, 32, 3058-3082. https://doi.org/10.1080/1331677X.2019.1655467

Asian Development Bank (2020). COVID-19 in the Kyrgyz Republic: Socioeconomic and Vulnerability Impact Assessment and Policy Response.

https://www.adb.org/documents/covid-19-kyrgyz-republic-socioeconomic-vulnerabilit y-impact

Bahoo, S., Alon, I., \& Floreani, J. (2021). Corruption in Economics: A Bibliometric Analysis and Research Agenda. Applied Economics Letters, 28, 565-578. https://doi.org/10.1080/13504851.2020.1764476

Baigubatova, N. R., \& Sarmanova, B. O. (2018). On the Issue of Corruption-Generating Factors in the Activities of the Penitentiary System of the Kyrgyz Republic. Journal of Foreign Law and Comparative Law, 4, 146-153.

Bystryantsev, S. B. (2009). The Fundamental Role of Methodology in Sociology and Other Social Sciences. Bulletin of the Russian State Pedagogical University, 117, 296-304.

Council of Europe Civil Law Convention on Corruption (1999). http://www.worldlii.org/int/other/treaties/COETSER/1999/2.html

Council of Europe Criminal Law Convention on Corruption (1999). http://www.consultant.ru/document/cons doc LAW 121544/

Edronova, V. N., \& Ovcharov, A. O. (2013). Methods, Methodology and Logic of Scientific Research. Economic Analysis: Theory and Practice, 9, 14-23.

Forbes (2021). 13 Largest Bribes in Modern Russian History. https://www.forbes.ru/obshchestvo-photogallery/376909-13-krupneyshih-vzyatok-v-no veyshey-istorii-rossii

G-20 Summit (2009). https://www.rand.org/events/g20.html

Gendler, G. E., \& Paksyutkin, A. A. (2006). Typology of Forms of Corruption. Proceedings of Higher Educational Institutions, North Caucasian Region. Social Sciences, No. S22, 12-16.

Ivanov, A. A. (2018). Constitutional Foundations of Combating Corruption in the Kyrgyz Republic. Law and Modern States, No. 2-3, 27-51.

KG24 (2021). Fight against Corruption. Top 10 Largest Bribes in Kyrgyzstan. https://24.kg/obschestvo/103292 borba skorruptsiey top-10 samyih krupnyih vzyato k vkyirgyizstane/

Khabibulina, A. A. (2011). 14. 2. Corruption as a Systemic Threat to the Financial Security of the Russian Federation. Problems of Economics and Legal Practice, No. 1, 244-250.

Kyrgyz Republic Ministry of Justice (2017). On Conflict of Interests. http://cbd.minjust.gov.kg/act/view/ru-ru/111716

Legislation. gov.uk (2006). Companies Act 2006. https://www.legislation.gov.uk/ukpga/2006/46/part/10/chapter/2 
Mangafić, J., \& Veselinović, L. (2020). The Determinants of Corruption at the Individual Level: Evidence from Bosnia-Herzegovina. Economic Research-Ekonomska Istraživanja, 33, 2670-2691. https://doi.org/10.1080/1331677X.2020.1723426

Muwema, T., \& Phiri, J. (2020). The Impact of Integrated Financial Management Information Systems on Procurement Process in Public Sector in Developing Countries-A Case of Zambia. Open Journal of Business and Management, 8, 983-996.

https://doi.org/10.4236/ojbm.2020.82062

Newsru.com (2013). “Corrupt Latin” Does Not Disappear from the Public Procurement Portal Budget Has Lost 874 Million.

https://www.newsru.com/finance/29may2013/govrublndtndr.html

OECD (1997). Convention on Combating Bribery of Foreign Public Officials in International Business Transactions.

https://www.congress.gov/treaty-document/105th-congress/43/document-text

Pertiwi, K. (2018). Contextualizing Corruption: A Cross-Disciplinary Approach to Studying Corruption in Organizations. Administrative Sciences, 8, 12. https://doi.org/10.3390/admsci8020012

Rezaev, A. V., \& Tregubova, N. D. (2012). Comparative Analysis in Sociology: Application Levels and Conceptual Problems. Journal of Sociology and Social Anthropology, $15,44-62$.

United Nations (2004). United Nations Convention against Corruption. https://www.unodc.org/documents/brussels/UN Convention Against Corruption.pdf

ZAKONY (2013). Czech Republic Act No. 304/2013 Coll.

https://www.zakonyprolidi.cz/cs/2013-304 